\title{
Multi-Faceted Roles of Giloy: A Mini-Review
}

\section{Ghosh $\mathrm{S}^{*}$}

Department of Biotechnology, Jai Prakash University, India

*Corresponding author: Dr. Somenath Ghosh, Assistant Professor and Head, Department of Zoology, Coordinator, Department of Biotechnology, Rajendra College, Jai Prakash University, Chapra-841301, Bihar, India, Tel: +91-9936439419; E-mail: somenath9936439419@gmail.

\section{Mini Review}

Volume 5 Issue 1

Received Date: January 06, 2021

Published Date: January 26, 2021

DOI: $10.23880 /$ jonam-16000293

com

\section{Abstract}

In Ayurveda, Giloy is considered one of the best medicines to treat various fevers and other conditions. Giloy is one of the three Amrit plants. Amrit means the 'root of immortality'. Hence, it is also called Amritavalli or Amrita in Sanskrit. Giloy is scientifically known as Tinospora cordifolia or Guduchi in Hindi. The stem of Giloy is considered highly effective because of its high nutritional content and the alkaloids found in it but the root and leaves also can be used. This herb activates the immune system of our body and increase vitality in a person. Inclusion of Giloy juice or kadha in diet twice a day can improve immunity. It is full of antioxidants and helps to release toxins from the body. Giloy juice also detoxifies skin and improves skin nourishment. Giloy is also used for liver diseases, urinary tract infections, and heart-related issues. Thus, Giloy can improve immunity and many other metabolisms in our body. However, more in depth researches are arrested to throw some light in immune enhancing activity of this herb.

Keywords: Amritavali; Ayurveda; Giloy; Immunity

\section{Introduction}

For centuries, we have been trying to make our life healthy with the resources set by nature, one of these herbs is also considered as Giloy. Which is not only used in Ayurvedic herbs, but Giloy is also being used in today's medicines. It was commonly used to treat fever, increase digestibility, etc. Although the stem of Giloy is most useful, we can use its root also. So let us now discuss the uses and benefits of using it since ancient times, it works to make our life healthy [1]. In Ayurvedic medicine, Guduchi (Giloy) is considered to be one of the three Amrit plants. Amrit means nectar of Gods, such are the qualities of this climber plant that in Sanskrit it named as "Amritavalli". Guduchi is welldocumented in Ayurvedic literature. Scientific studies also evaluate and confirm the insight beneficial properties of this medicinal herb like Immune modulatory, Hepato-protective, Cardio-protective, Anti-inflammatory, Antioxidant, Analgesic effect, confirms the Ayurvedic view of Guduchi as a Rasayana (rejuvenator) and an immunity booster [2].

\section{Multi Factorial Functions of Giloy}

First of all, if we talk about the benefits of using Giloy, its use helps in boosting immunity. Giloy performs important functions to keep our cells healthy and rid us of disease. Along with this, it is also considered appropriate to purify the blood, fight bacteria, remove toxins, etc. Considered to be antipyretic, Giloy is also considered very beneficial for fighting dangerous diseases such as dengue, swine flu, malaria and is used to relieve fever [3].

\section{$>$ Boosts Immunity}

Guduchi is recognized to accord longevity, enhances memory, improves health, and bestows youth. This herb activates the immune system of the body, boosting immunity and promoting vitality in a person [4]. 


\section{Journal of Natural \& Ayurvedic Medicine}

\section{$>$ Detoxification}

Guduchi works as a detoxifier and improves complexion and luster of the skin. People suffering from skin ailments often apply the Guduchi plant oil on the affected areas. It is also popular as a skin lotion, considering the fact that it improves skin complexion and enhances the general health of the skin [5].

\section{$>$ Effective against respiratory Infections}

Guduchi has been preferred traditionally to treat ailments such as bronchitis and chronic cough. It pacifies the mucous membrane of respiratory system thereby making it very effective against asthma [4].

\section{$>$ Boosts Liver function}

Giloy or Guduchi has the ability to detoxify liver and help in proper functioning. It might also act as a remedy for fatty liver. One of the biggest benefits of Guduchi is that it can help stimulate the regeneration of liver tissue that has been damaged [4].

\section{$>$ Improves Digestion}

Guduchi works towards building a stronger digestive system and immunes body against hyperacidity, colitis, worm infestations, and loss of appetite, abdominal pain, excessive thirst, and vomiting [4].

\section{$>$ Reduces Stress and anxiety}

Giloy is an excellent adaptogenic herb, which means that it helps in managing stress and anxiety by normalizing your physiological functions. It has a calming effect on the body. Due to its ability to cross the blood brain barrier, Guduchi has the power to enhance memory and cognitive functions [5].

\section{$>$ Health Rejuvenator}

This medicinal herb is a health rejuvenator which is also widely known for its effectiveness in enhancing natural immunity to fight against a number of illnesses such as fever, jaundice, skin diseases, constipation and tuberculosis [6].

\section{$>$ Anti-ageing Properties}

The anti-ageing properties in Gudduchi helps in reducing wrinkles, dark spots, fine lines and pimples resulting in flawless and glowing skin [4].

\section{$>$ Anti-Inflammatory Properties}

Guduchi is known for its anti-inflammatory properties which provide relief while dealing with inflammatory conditions such as gout and arthritis. Clinical evaluations have shown to significantly reduce pain in patients with rheumatoid arthritis.

\section{$>$ Brings down fever}

Guduchi helps in bringing high fever under control by lowering the body temperature. It is very effective while dealing with intermittent fevers [6].

\section{$>$ Promotes Sexual Health}

Giloy is well known in Ayurveda for its aphrodisiac benefits. It can effectively tackle various sexual health issues such as impotence and involuntary ejaculation [5].

\section{$>$ Improves Eye-sight}

Giloy might help in improving the clarity of vision. In order to get the benefits of Giloy for your eyesight, boil Guduchi powder or Guduchi leaves in water. Once it cools down apply it on the eye lids [5].

\section{$>$ Treats Arthritis}

Giloy contains anti-arthritic properties that help to treat arthritis and its several symptoms. For joint pain, the powder from giloy stem can be boiled with milk and consumed [6].

\section{$>$ Treats Diabetes}

This herb helps in managing the level by assisting in the production of insulin. Giloy can also burn excess glucose and reduce the level of blood sugar. Giloy works in this regard due to its hypo-glycaemic effects [1].

\section{$>$ Healing Wounds}

Giloy also helps in stimulating phagocytic cells which helps in healing wounds. One can apply Giloy leaf paste on the skin to speed up the wound healing process as it helps skin regeneration [4].

\section{Evaluation of toxicity of giloy extract in animal models}

\section{$>$ Administration of melatonin loaded giloy extracts in animals \\ Impact of toxicity (if any) of giloy extracts were evaluated} in rats. Animals were divided into two groups (control and nanoparticle treated; $\mathrm{n}=5$ /group) with ad libitum access to commercially available animal palette and water. In the control group, animals were administrated with normal saline where the treated animals received aqueous extract of giloy. After 7 days, animals were sacrificed and blood and desired tissues (liver and kidney) were collected and were homogenized in respective buffers and were processed for evaluation of different immunological parameters and evaluation of toxicity in terms of Liver Function Test (LFT) and Renal Function Test (RFT).

\section{$>$ Evaluation of toxic impacts of giloy extract}

Any kind of foreign chemical introduced in body can evoke different physiological side-effects which are mainly of two types. 1. Toxic effects. 2. Immunological side effects. Thus, to evaluate the same we assessed the LFT and RFT in 
both control and giloy extract treated groups.

\section{$>$ Effect on Liver Function Test (LFT)}

Serum Glutamic Oxaoacetate Transaminase (SGOT or Aspertate Aminotransferase; AST) and Serum Glutamic Pyruvic Transaminase (SGPT or Alanine Aminotransferase) are stored in liver under normal conditions [7-12]. But, upon clinical conditions where the liver is injured (which may be induced due to any kind of drug treatment or due to alcoholic shock) the level of both SGOT and SGPT may be elevated. Thus, assessment of SGOT and SGPT are regarded as the universal markers of liver function. Upon giloy extract treatment we noted significantly low levels ( $p>0.05$ ) of SGOT and SGPT as compared to control in plasma and liver. This provided us the first clue that the giloy extract treatment is not going to affect the most biochemically efficient organ of the body; i.e. the liver. Further, we were interested in evaluating the functioning of another physiologically important organ i.e. the kidney which was assessed by Renal Function Test (RFT).

\section{$>$ Effect on Renal Function Test (RFT)}

Kidney is one of the most important organs of body actively and effectively participating in detoxification. Any kind of drug administration may hamper renal function as well as glomerular filtration rate (GFR; [13-18]), hence our next aim was to investigate the Renal Function Test (RFT) by assessing plasma urea, Blood Urea Nitrogen (BUN), creatinine, Alkaline Phosphatase (ALP) and Acid Phosphatase (ACP). We noted significantly low levels ( $p>0.05$ ) of plasma urea, BUN and creatinine levels in giloy extract treatment groups; however the ACP and ALP levels were found to be unaffected as compared to control. Thus, our results have suggested that the giloy extract treatment neither had negative impact on liver function nor had negative effect on kidney function. But, any kind of drug treatment (including the giloy extract) can evoke immunological anomaly in body. Hence, our next aim was to investigate the status of cell mediated and humoral immune parameters upon giloy extract treatment.

\section{Evaluation of immunological effects of giloy extract}

\section{$>$ Effect on Cell mediated Immune Parameters:}

The cell mediated immune parameters are the first marker for any kind of immunogenic or hypersensitivity reaction [19-23]. To assess the same, we noted significantly high $(\mathrm{p}<0.05)$ levels of Total Leukocyte Count (TLC), Differential Leukocyte Count (DLC) and \% Lymphocyte Count (\%LC) upon giloy extract treatment as compared to control. These results suggested that, the elevated levels of peripheral cellular components of immunity may be due to some kind of hypersensitivity reaction because of giloy extract treatment. To investigate the same, we noted humoral immune parameters i.e. cytokines.

\section{$>$ Effect on Humoral Immune Parameters}

The open circuit of blood immune parameters is chemically coordinated by lymphokines, chemokines and cytokines. Among them, the most effective are the cytokines which are producing the broadest spectrum coordinating a number of immunologically active cells. The cytokines are mainly of three types pro-inflammatory (e.g. IL-2), antiinflammatory (e.g. IL-6) and switch between pro-and antiinflammation (e.g. TNF- $\alpha$; [24-29]). We noted significantly high $(\mathrm{p}<0.05)$ levels of IL- 2 and TNF- $\alpha$ and significantly low ( $p>0.05$ ) levels of IL- 6 and IL-1 $\beta$ (a cytokine directly associated with plasma cortisol; [30-32]) in giloy extract treatment group in comparison to control. Further, IFN- $\gamma$ (a particular cytokine marker for viral infection, [33]) was found unaffected both in control and giloy extract treatment group.

\section{Conclusion}

Our preliminary findings have suggested that the effect of giloy is without any side effects and it is definitely a proimmunogenic molecule. It is slowly gaining popularity in all parts of the world as a preventive and clinical medicine. The importance of this wonder herb is increasing day by day as more and more people start knowing the uses of Guduchi (Giloy). However, mor in depth studies are arrested for assessment of immunomodulatory impact of giloy in human for its putative use human as an alternative medicine.

\section{Acknowledgement: NIL}

\section{Conflict of Interest: NIL}

\section{Consent to Publish: YES}

\section{References}

1. www.patanjaliayurved.net

2. www.dabur.com

3. www.ayurved.com

4. www.mavcure.com

5. www.banyanbotanicals.com

6. www.bimbina.com

7. Matera L, Mori M (2000) Cooperation of pituitary hormone prolactin with interleukin-2 and interleukin-12 on production of interferon-gamma by natural killer and T cells. Ann N Y Acad Sci 917: 505-513.

8. Hermus AR, Sweep CG (1990) Cytokines and the 
hypothalamic-pituitary-adrenal axis. J Steroid Biochem Mol Biol 37(6): 867-871.

9. Harbuz MS, Lightman SL (1992) Stress and the hypothalamo-pituitaryadrenal axis: acute, chronic and immunological activation. J Endocrinol 134(3): 327-339.

10. Withyachumnarnkul B, Nonaka KO, Santana C, Attia AM, Reiter RJ (1990) Inferferon-gamma modulates melatonin production in rat pineal glands in organ culture. J Interferon Res 10(4): 403- 411.

11. Kim CK, Turnbull AV, Lee SY, Rivier CL (1999) Effects of prenatal exposure to alcohol on the release of adenocorticotropic hormone, corticosterone, and proinflammatory cytokines. Alc Clin Exp Res 23(1): 5259.

12. Colombo N, Peccatori F, Paganin C, Bini S, Brandley M, et al. (1992) Anti-tumour and immunomodulatory activity of intraperitoneal IFN-gamma in ovarian carcinoma patients with minimal residual tumor after chemotherapy. Int J Cancer 51(1): 42-46.

13. Salkowski CA, Vogel SN (1992) Lipopolysaccharide increases glucocorticoid receptor expression in murine macrophages. A possible mechanism for glucocorticoidmediated suppression of endotoxicity. J Immunol 149(2): 41-47.

14. Blalock JE (1994) Shared ligands and receptors as a molecular mechanism for communication between the immune and neuroendocrine systems. Ann, NY Acad Sci 741: 292-298.

15. Chen HF, Jeung EB, Stephenson M, Leung PC (1999) Human peripheral blood mononuclear cells express gonadotropin-releasing hormone (GnRH), GnRH receptor, and interleukin-2 receptor gamma-chain messenger ribonucleic acids that are regulated by $\mathrm{GnRH}$ in vitro. J Clin Endocr Metab 84(2): 743-750.

16. Tolosa E, Ashwell JD (1999) Thymus-derived glucocorticoids and the regulation of antigen-specific T-cell development. Neuroimmunomod 6(1-2): 90-96.

17. Urszula K, Helen R, Strausser JP, Bressler AL (1981) Effects of Sex Hormones on Some T and B Cell Functions, Evidenced by Differential Immune Expression Between Male and Female Mice and Cyclic Pattern of Immune Responsiveness During the Estrous Cycle in Female Mice. Gen Comp Endocrinol 1(2): 73-77.

18. Nagy E, Baral E, Berczi I (1999) Immune System, Estrogens and Antiestrogens IHandbook of Experimental Pharmacology. 135: 343-351.

\section{Journal of Natural \& Ayurvedic Medicine}

19. Okuyam R, Abo T, Seki S, Ohteki T, Suguira K, et al. (1992) Estrogen administration activates extrathymic $\mathrm{T}$ cell differentiation in liver. J Exp Med 175(3): 661-669.

20. Leposavic G, Obradovic S, Kosec D, Pejcic-Karapetrovic B, Vidic-Dankovic B (2001) In vivo modulation of the distribution of thymocyte subsets by female sex steroid hormones. Int Immunopharmacol 1(1): 1-12.

21. Screpanti I, Morrono S, Meco D, Santoni A, Gulino A, et al. (1989) Steroid sensitivity of thymocyte subpopulations during intrathymic differentiation, Effects of 170-estradiol and dexamethasone on subsets expressing $\mathrm{T}$ cell antigen receptor of IL-2 receptor. J Immunol 142(10): 3378-3383.

22. Medina VM, Dawson-Basoa ME, Gintzler AR (1993) 17 beta-estradiol and progesterone positively modulate spinal cord dynorphin: relevance to the analgesia of pregnancy. Neuroendocrinol 58(3): 310-315.

23. Smithson G, Medina K, Ponting I, Kincade PW (1995) Estrogen suppresses stromal cell-dependent lymphopoiesis in culture. J Immunol 155(7): 3409-3417.

24. Kincade PW, Medina KL, Payne KJ, Rossi MI, Tudor KS, et al. (2000) Early B-lymphocyte precursors and their regulation by sex steroids. Immunol Rev 175: 128-137.

25. Verthelyi D, Ahmed SA (1997) Characterization of estrogen-induced autoantibodies to cardiolipin in nonautoimmune mice. J Autoimmun 10(2): 115-125.

26. Kanda N, Tsuchida T, Tamaki K (1999) Estrogen Enhancement of Anti-Double-Stranded Dna Antibody And Immunoglobulin G Production In Peripheral Blood Mononuclear Cells From Patients with Systemic Lupus Erythematosus. Arth Rheum 42(2): 328-337.

27. Bateman A, Singh A, Kral T, Solomon S (1989) The immune-hypotalamic-pituitary-adrenal axis. Endocr Rev 10(1): 92-112.

28. Khansari ON, Murgo AJ, Faith RE (1990) Effects of stress on the immune system. Immunol Today 11: 170-175.

29. Del Rey A, Besedovsky HO, Sorkin E, Da Prada M, Arrenbrecht S (1981) Immunoregulation mediated by the sympathetic nervous system, II. Cell Immun 63(2): 329-333.

30. Kitay JI (1961) Sex differences in adrenal cortical secretion in the rat. Endocrinol 68: 818-824.

31. deKloet ER, Oitzl MS, Joels M (1993) Functional implications of braincorticosteroid receptor diversity. Cell Mol Neurobiol 13(4): 433-455. 


\section{Journal of Natural \& Ayurvedic Medicine}

32. Nelson RJ, Demas GE (1996) Seasonal changes in immune function. Q Rev Biol 71(4): 512-548.
33. Demas GE (2004) The energetics of immunity: a neuroendocrine link between energy balance and immune function. Horm Behav 45(3): 173-180. 